\title{
Whose Larynx Is It? Fields of Scholarly Competence around 1900
}

\author{
Viktoria Tkaczyk, Humboldt University Berlin/Max Planck Institute \\ for the History of Science
}

\begin{abstract}
A BSTRACT
In the late nineteenth century, German philosophers such as Wilhelm Dilthey began to build epistemological foundations for the divergent epistemic interests of the humanities and the natural sciences. At the same time, controversy arose around new fields of research, such as "experimental aesthetics," that might be affiliated with either area. This article focuses on this controversy in German academia by tracing how the larynx of singers, actors, concertgoers, readers, and theater audiences became a crucial object of investigation in experimental aesthetics - bringing together disciplines as varied as physiology, psychology, laryngology, phonetics, sound engineering, musicology, literary studies, and theater studies. The article considers why experimental aesthetics achieved such success between approximately 1890 and 1930, why it later disappeared from the academic landscape, and why it has returned in the last decade under the name "empirical aesthetics."
\end{abstract}

$\mathrm{f}$ it is true that every era has its own research objects, then the larynx is certainly a privileged object of the period around 1900. The invention of the laryngoscope by the Spanish opera singer Manuel P. Rodríguez García had been followed in the 1860 s by the rise of a new medical specialty, laryngology (fig. 1). Rapid developments in measurement technology (laryngeal probes, brushes, electrodes, etc.) soon attracted the attention of other disciplines to the larynx and its workings, almost imperceptible from outside.

Most prominent among these fields was experimental phonetics. The French phonetician Abbé Pierre-Jean Rousselot, for example, developed an external language explorer (explorateur externe de la langue) in the 1880 s to graphically record the laryngeal

Translated by Kate Sturge.

History of Humanities, Volume 3, Number 1. http://dx.doi.org/10.1086/696302

(C) 2018 by Society for the History of the Humanities. All rights reserved. 2379-3163/2018/0301-0006\$10.00 


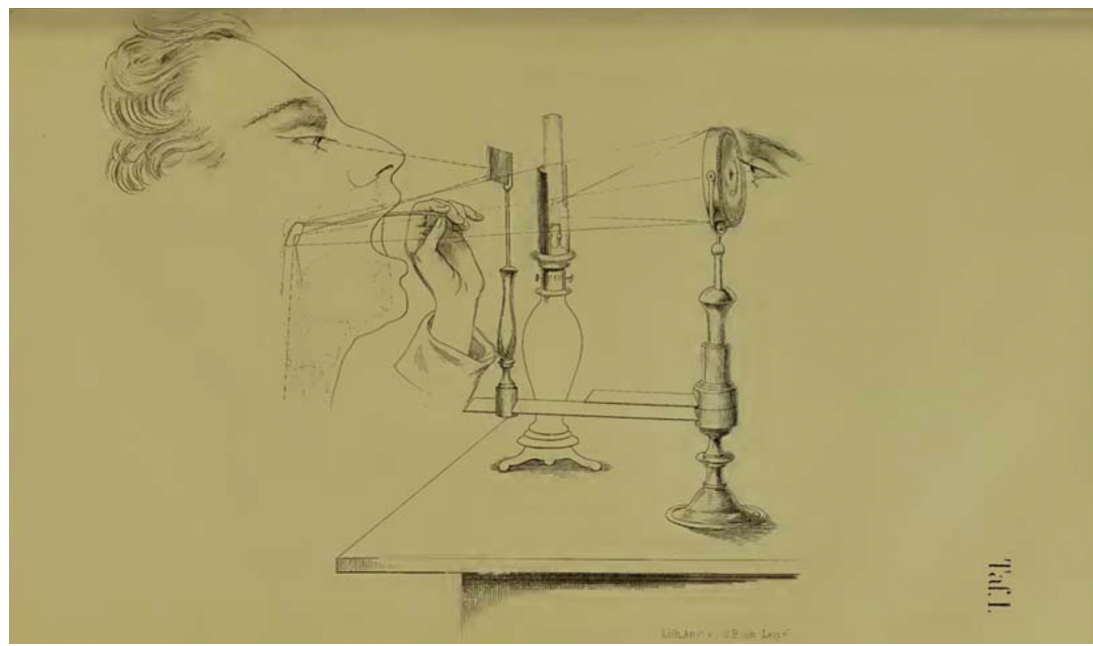

Figure 1. Laryngoscope. Johann N. Czermak, Der Kehlkopfspiegel und seine Verwendung für Physiologie und Medizin (Leipzig: Engelmann, 1860), 109.

movements of speakers of patois in his hometown, Cellefrouin (fig. 2). And when he was appointed head of the experimental phonetics laboratory at the Collège de France in Paris, Rousselot presented a series of new devices for measuring and comparing the laryngeal movements of speakers of several other languages. ${ }^{1}$ Rousselot's work illustrates how phoneticians, traditionally trained in philology, now became experts in research fields more closely associated with the natural sciences, such as laryngology and acoustic engineering.

But researching the larynx did not necessarily mean adopting the methods and technologies of the natural sciences. In some domains, the larynx became a topos enabling the definition or assertion of new approaches in the humanities. This was especially true for a group of disciplines just emerging around 1900 in the arts - literary studies, musicology, theater studies - that were also interested in the prickle in the throat a person experiences when reading a book, listening to music, or watching a performance. In this contribution, I follow the larynx on its journey through these disciplines to closely examine the variable relationship between the humanities and the natural sciences. I zoom in on a German network of scholars who shared an interest in "experimental aesthetics" but differed greatly in their approaches. ${ }^{2}$

1. Jean-Pierre Rousselot, Principes de phonétique expérimentale, vol. 1 (Paris: Didier, 1897-1901), 93-96 and 244-60. On Rousselot, see Robert Brain, The Pulse of Modernism: Physiological Aesthetics in Fin-de-Siècle Europe (Seattle: University of Washington Press, 2015), 64-92.

2. I thank the editor of this forum section for giving me the opportunity to revisit some material that is discussed in Viktoria Tkaczyk, "Max Herrmann und die Austreibung des Geistes aus der The- 


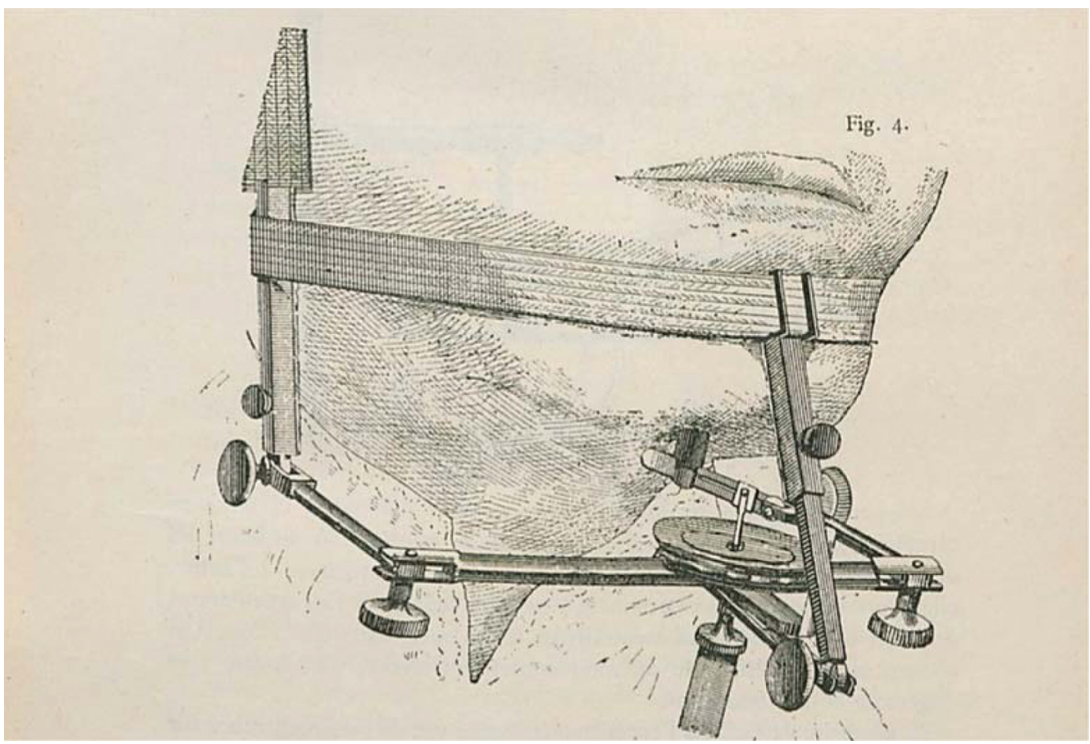

Figure 2. External language explorer. Pierre-Jean Rousselot, Les modifications phonétiques du langage étudiées dans le patois d'une famille de Cellefrouin (Charente) (Paris: H. Welter, 1891), 11.

The present essay builds on recent scholarship that has pointed to "shared processes of knowledge production" and "epistemic-disciplinary crossovers" in the field of experimental aesthetics around 1900. ${ }^{3}$ Most of this literature is interested in the "exchange of instruments, concepts, and media of representation between the sciences and the arts," while some also identifies "systematic variations or 'schools' of aesthetic research" such as experimental physiology, empirical psychology, or the philosophical aesthetics of empathy. ${ }^{5}$ A closer look at research on particular objects such as the larynx renders these variations even more visible - prompting me to argue that in these cases the "great divide" cannot essentially be found between the "humanities and the natural

aterwissenschaft," in Perspektiven auf Max Hermann: 100 Jahre Forschungen zur deutschen Theatergeschichte, ed. Stephan Dörschel and Matthias Warstat (Berlin: Gesellschaft für Theatergeschichte, forthcoming).

3. Marie Guthmüller and Wolfgang Klein, "Einleitung: Ästhetik von unten-Empirie und ästhetisches Wissen," in Ästhetik von unten, ed. Marie Guthmüller and Wolfgang Klein (Tübingen: Francke, 2006), 5; Jutta Müller-Tamm, Henning Schmidgen, and Tobias Wilke, "Empirische Ästhetik um 1900: Zur Einführung," in Gefühl und Genauigkeit, ed. Jutta Müller-Tamm, Henning Schmidgen, and Tobias Wilke (Munich: Fink, 2014), 9.

4. Robert M. Brain, "The Pulse of Modernism: Experimental Physiology and Aesthetic AvantGardes circa 1900," Studies in History and Philosophy of Science Part A 39, no. 3 (2008): 393-417, 393.

5. Müller-Tamm, Schmidgen, and Wilke, "Empirische Ästhetik um 1900," 10-11. See also Susan Lanzoni, "Introduction: Emotion and the Sciences," Science in Context 25, no. 3 (2012): 287-300. 
sciences avant la lettre." Rather the "great divide" zigzagged on a much smaller scale within particular disciplines, schools, or even closely related scholars.

\section{THE LARYNX OF MUSIC}

In his Tonpsychologie of 1883, philosopher Carl Stumpf speculated about whether the voices of dead singers or actors were preserved in their "laryngeal memory." "A Viennese physician has recently examined the larynxes of famous singers and did not find anything particular about them," wrote Stumpf, "but in the nuclei that connect the center of volition with the larynx and combine the muscle fibers into collective activity, there must be innate differences which predispose these people to finer mobility and greater muscle sensitivity; in addition, perhaps also distinctions in the connecting paths between the sound and muscle centers, etc."

Stumpf's view of individual differences in "muscle sensitivity" rested on insights from neuroanatomy and psychophysiology. Since the 1860s, researchers in these fields had begun to regard the human brain as a neuronal network associating different centers (visual, auditory, taste, motor) and the corresponding nerve pathways. Despite numerous disputes, there was agreement that when speaking or making music, human beings utilized both their acoustic memory and motor memories (e.g., memories of the motions of one's own speech organs) that were not confined to the motor center of the cortex, but also inscribed themselves into the body, partially in the form of a "la-

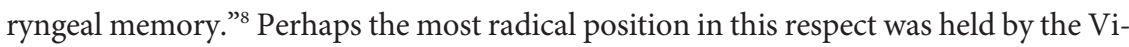
ennese pathologist Salomon Stricker, who argued that every memory is primarily a motor image and every form of attention is accompanied by inner movements - that is, even processes such as listening to music or reading a book are impossible without muscle feelings (Muskelgefühle) in the laryngeal area. ${ }^{9}$

Stricker was most probably the "Viennese physician" that Stumpf had in mind when he speculated about the laryngeal memory of the deceased. But although Stumpf agreed with Stricker that "tonal sensation [Tonempfindung] and laryngeal innervation" were

6. Carl Stumpf, Tonpsychologie, vol. 1 (Leipzig: Hirzel, 1883), 295.

7. Ibid., 295. Stumpf seems to have been referring to Salomon Stricker, Studien über die Bewegungsvorstellungen (Vienna: Braumüller, 1882); or to the then unpublished works by Leopold Schrötter (Vorlesungen über die Krankheiten des Kehlkopfes, der Luftröhre, der Nase und des Rachens [Vienna: Wilhelm Braumüller, 1887]) and Johann Schnitzler (Klinischer Atlas der Laryngologie nebst Anleitung zur Diagnose und Therapie der Krankheiten des Kehlkopfes und der Luftröhre [Vienna: Braumüller, 1895]).

8. See Michael Hagner, Der Geist bei der Arbeit: Historische Untersuchungen zur Hirnforschung (Göttingen: Wallstein, 2006), 38-58.

9. Stricker, Studien über die Bewegungsvorstellungen, 19 and 35. 
usually interdependent, ${ }^{10}$ he criticized him for relying mainly on very general neuroanatomical schemata and, for his psychological claims, on single introspection-based observations. Stumpf, in contrast, was seeking to establish a new psychological approach that united physiological findings, introspection, experimental methods, and the comparison of multiple test subjects. These methods showed Stumpf that not everyone who listened to music felt a prickle in the throat. Some of his test subjects listened only with their ears (and their tonal memory). Furthermore, a person might "possess a very refined judgment of tones but a very clumsy larynx, or vice versa." ${ }^{\text {"1 }}$

Stumpf's interest in individually differing sensory perceptions has often been described as part of the history of cultural psychology. Although Stumpf himself did not use this term, in the 1890s his approach opened the door to a much-contested position at the University of Berlin, where the philosopher Wilhelm Dilthey was instrumental in crystallizing out epistemological distinctions between the humanities and the sciences. ${ }^{12}$ During that process of differentiation, controversy arose around the affiliation of research fields, such as psychology, that might belong to either side. Whereas Dilthey's "understanding psychology" addressed the cognitive and interpretive capacities of the (culturally shaped) human mind, psychologists working with experimental methods from the natural sciences focused more generally on the workings and manipulability of human perception and judgment. In 1893, the apparent irreconcilability of these approaches led Dilthey to block the appointment of the experimental psychologist Hermann Ebbinghaus as a professor of philosophy at the University of Berlin. Considering Ebbinghaus's research a "scientific radicalization of philosophy,"13 Dilthey chose instead to back the Gestalt psychologist Carl Stumpf, who was also appointed head of the soon to be famous Institute of Psychology, which stood for a new holistic, but — even if against Dilthey's will—still experimental, method. ${ }^{14}$

Among other areas, Stumpf's work achieved great prominence in the aesthetics of empathy (Einfühlungsästhetik), another subdiscipline of philosophy, which aimed to describe the sense of beauty in art no longer metaphysically but exclusively in psychophysiological terms. The Giessen philosopher Karl Groos, for example, references

10. Stumpf, Tonpsychologie, 1:155.

11. Ibid., 164 .

12. Wilhelm Dilthey, Introduction to the Human Sciences, trans. Michael Neville and ed. Rudolf A. Makkreel and Frithjof Rodi (1883; Princeton, NJ: Princeton University Press, 1989).

13. Erich Rothacker, ed., Briefwechsel zwischen Wilhelm Dilthey und dem Grafen Paul Yorckv. Wartenburg, 1877-1897 (Halle: Niemeyer, 1923), 165.

14. Bernhard Siegert, "Das Leben zählt nicht: Natur- und Geisteswissenschaften bei Dilthey aus mediengeschichtlicher Sicht," in Medien: Dreizehn Vorträge zur Medienkultur, ed. Claus Pias (Weimar: VDG, 1999), 161-82, 180-81. 
Stumpf's work in Der aesthetische Genuss (Aesthetic enjoyment) of $1902 .{ }^{15}$ Groos regarded the inward imitation of artistic works as the "real center of aesthetic enjoyment." ${ }^{16}$ All perception, he argued (unlike Stumpf), is accompanied by forms of inner imitation, and the boundary between aesthetic and nonaesthetic perception is fluidbut some artistic genres stimulate the viewer more strongly than others: "In the cases of poetry and, especially, music, this inward imitation may become so strong that it pushes out from the inside and becomes physically visible. Involuntarily, one imitates the changing expression of the actor's face, or one accompanies the movement of the music by rocking the upper body, by swaying the head to and fro." ${ }^{17}$ According to Groos, the imitative drive came to bear wherever human behavior was not defined by heredity and instinct alone. ${ }^{18}$ It was particularly easy to see in the case of the child; in the adolescent, it was internalized. In his later work, Groos also described empathy as a kinesthetic reproduction of movements already experienced. ${ }^{19}$ His example was the spectator in the theater auditorium, inwardly talking along with the performance, in whom "such innervations often occur, just as, more generally, in the motorically gifted every marked imagining of a movement and direction tends to affect the relevant muscle parts." ${ }^{20} \mathrm{Al}-$ though Groos himself compared the audiences of various art genres only en passant, for the arts comparisons between music listeners, readers, and theater audiences would become crucial.

\section{TURNING THE READER'S VOICE INSIDE OUT}

Probably the most systematic research on reading was conducted at Wilhelm Wundt's laboratory for experimental psychology at the University of Leipzig. ${ }^{21}$ Wundt's psychophysical parallelism - the hypothesis of a generally applicable correspondence and constant mutual influence of physical and psychological processes - shared Stumpf's interest in experimental aesthetics, but differed fundamentally from the comparative approach that Stumpf aimed to establish in Berlin. ${ }^{22}$ Unsurprisingly, in 1912, Wundt's student Rudolf Pintner criticized the introspective approaches to studying unconscious

15. Karl Groos, Der aesthetische Genuss (Giessen: Ricker, 1902), 189 and 198.

16. Ibid., 183.

17. Karl Groos, Einleitung in die Aesthetik (Giessen: Ricker, 1892), 86-87.

18. Ibid., 201-3.

19. Karl Groos, "Das ästhetische Miterleben und die Empfindungen aus dem Körperinnern," Zeitschrift für Ästhetik und allgemeine Kunstwissenschaft 4 (1909): 178-79.

20. Ibid., 175.

21. For Wundt's earliest reference to research on inner speech, see Wilhelm Wundt, Die Sprache: Erster Teil, vol. 1 of Völkerpsychologie (Leipzig: Engelmann, 1900), 551.

22. Ibid., 65. 
motions that were practiced by Stumpf and others when they examined the larynxes of music listeners. ${ }^{23}$ When Pintner examined the involuntary repetition of words during reading, he advocated instead for more objective measurements of the movements of the larynx and tongue, like those done in American laboratories for experimental psychology. ${ }^{24}$ Pintner experimented on the behavior of people reading while simultaneously counting aloud (the aim being to suppress their unconscious movements) and discovered that the test subjects' reading rate and comprehension improved when their "inner speech" was eliminated. ${ }^{25} \mathrm{He}$ doubted, however, that readers could be completely weaned away from the habit of articulation - a habit "of such long standing and so deeply rooted in the

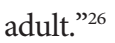

Another field concerned with inner speech was the "philology of speech and the ear" propounded by the Leipzig phonetician Eduard Sievers, ${ }^{27}$ famous in its day among linguistic and literary scholars, theologians, and physiologists and already the subject of research by historians of science. ${ }^{28}$ If I return to the "philology of the ear" here, it is because of the trail that leads from Wundt and Pintner to Sievers, from Sievers to the Germanist Julius Petersen, and from there to theater scholar Max Herrmann.

From around 1900, Sievers aspired to find new ways of examining historical texts. On the grounds that "a good declamation, a good performance is the best commentary on a piece of literature, ${ }^{29}$ he supplemented silent textual study with a performative method. Reading aloud or reciting would, he believed, reproduce the text's "inner musical characteristics": ${ }^{30}$ the pitch, modulation, tone steps, and rhythm of the author's voice. ${ }^{31}$ In what would later be called "sound analysis" (Schallanalyse), ${ }^{32}$ Sievers identi-

23. Rudolf Pintner, Untersuchungen über die Aufmerksamkeitsformen beim Lesen und Reagieren (Leipzig: Hahn, 1913), and "Inner Speech during Silent Reading," Psychological Review 20, no. 2 (1913): 129-53.

24. H. S. Curtis, "Automatic Movements of the Larynx," American Journal of Psychology 11, no. 2 (1900): 237-39; H. C. Courten, "Involuntary Movements of the Tongue," Yale Psychological Studies 10 (1902): 93-95. See Pintner, "Inner Speech," 136.

25. Pintner, "Inner Speech," 151-53.

26. Ibid., 153.

27. Eduard Sievers, "Über ein neues Hilfsmittel philologischer Kritik" (1903), in Rhythmischmelodische Studien (Heidelberg: Winter, 1912), 78.

28. Gerold Ungeheuer, Sprache und Signal (Hamburg: Buske, 1977), 85-113; Reinhart MeyerKalkus, Stimme und Sprechkünste im 20. Jahrhundert (Berlin: Akademie-Verlag, 2001), 73-125.

29. Eduard Sievers, "Zu Rhythmik und Melodik des neuhochdeutschen Sprechverses" (1894), in Rhythmisch-melodische Studien (Heidelberg: Winter, 1912), 39.

30. Sievers, "Über ein neues Hilfsmittel," 110.

31. Eduard Sievers, "Über Sprachmelodisches in der deutschen Dichtung" (1901), in Rhythmischmelodische Studien (Heidelberg: Winter, 1912), 66.

32. Eduard Sievers, Ziele und Wege der Schallanalyse: Zwei Vorträge (Heidelberg: Winter, 1924). 


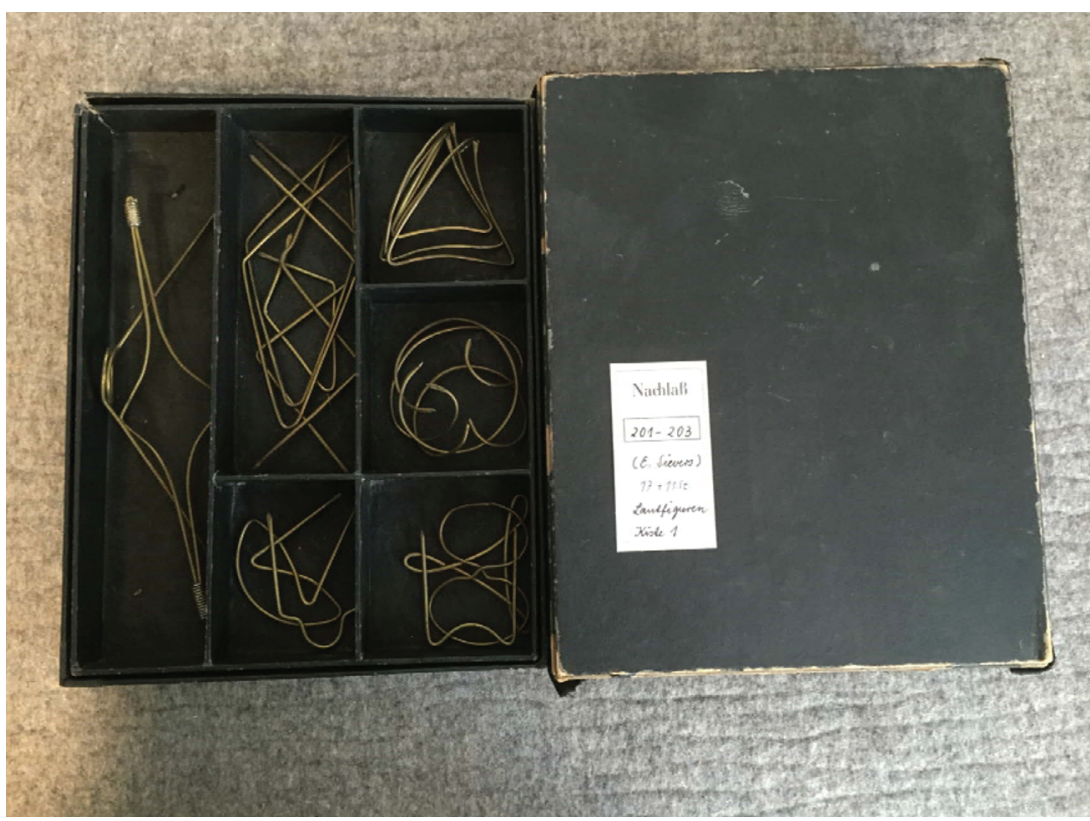

Figure 3. Sievers's optical signals, Nachlaß 201-203 (E. Sievers), box 1, University Archive Leipzig

fied six types of authorial voice and ninety-six subordinate "voice varieties." ${ }^{\text {33 }} \mathrm{A}$ willing reader, Sievers argued, could "instinctively" feel his way into a text's voice type, ${ }^{34}$ sensing it through his own "bodily disposition" while reading aloud. ${ }^{35}$ To make his results usable by both readers and philologists, Sievers visualized the types with shapes he called "personal curves" and produced "optical signals": ${ }^{36}$ a set of brass-wire figures enabling the correct vocal disposition (cold or warm, major or minor, lyrical or dramatic) to be found while declaiming (fig. 3).

Sievers was probably familiar with Pintner's studies, but his interest was in the articulation of the reader's inner voice, not its repression. In 1917, Sievers and Willy E. Peters carried out an experiment to this effect at Wundt's Psychological Institute in

33. Eduard Sievers, "Neues zu den Rutzschen Reaktionen," Archiv für experimentelle und klinische Phonetik 1 (1914): 235, and Metrische Studien IV: Die Altschwedischen Upplandslagh nebst Proben formverwandter Germanischer Sagdichtung (Berlin: Springer, 1918), 32.

34. Sievers, "Neues zu den Rutzschen Reaktionen," 229. Sievers is drawing on the speculative theory of Oberammergau singing teacher Josef Rutz, problematic due to its crude vocal physiognomy. See Ottmar Rutz, Musik, Wort und Körper als Gemütsausdruck (Leipzig: Breitkopf \& Härtel, 1911).

35. Sievers, Ziele und Wege, 29.

36. Ibid., 33, and Sievers, "Neues zu den Rutzschen Reaktionen," 235. 


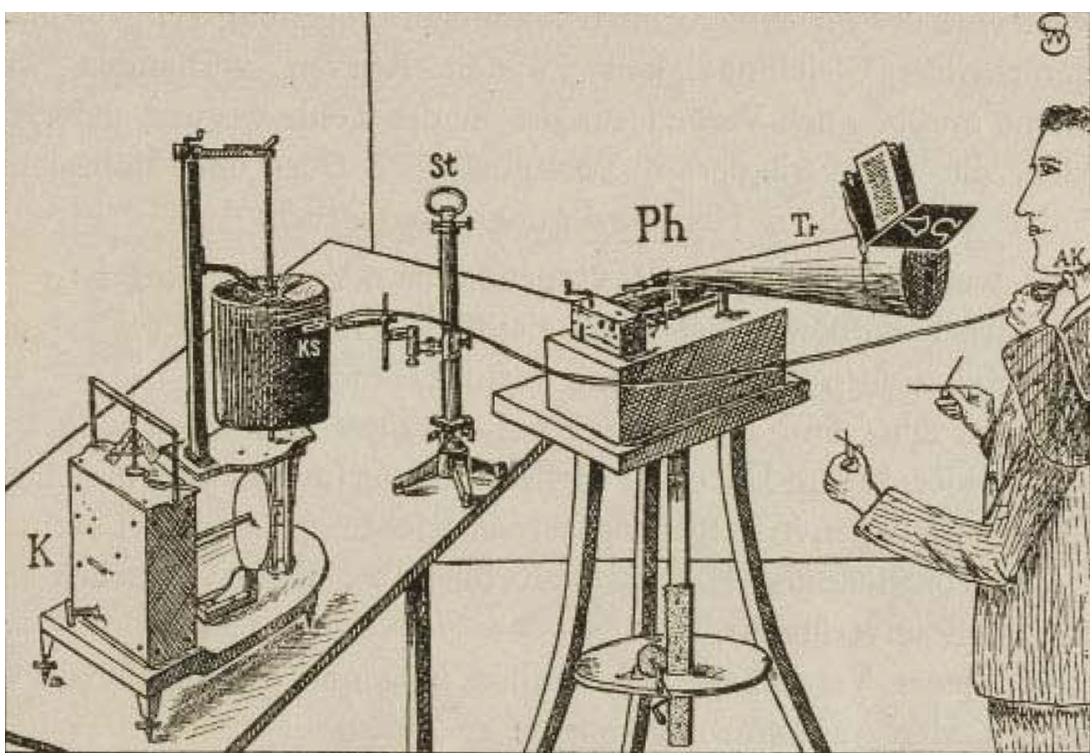

Figure 4. Reading experiments. Willy E. Peters, "Stimmgebungsstudien. I: Der Einfluß der Sievers'schen Signale und Bewegungen auf die Sprachmelodie. Experimentalphonetisch untersucht," Psychologische Studien 10 (1917): 393.

Leipzig. Eight test subjects (including Sievers) declaimed Schiller's ballad "Rudolf of Hapsburg," holding Sievers's optical signals in their hands for stimulation. ${ }^{37}$ The readers' unconscious "inner vibrations" were registered with a recording capsule and a kymograph held to the larynx while they spoke into a phonograph horn. The resulting laryngographic curves were then transferred to music staff paper and compared with the phonograms (fig. 4). Peters and Sievers identified a broadly similar vocal adaptation to the text among all the test subjects, visible in similar motions of the laryngeal musculature. $^{38}$

Later on, Sievers abandoned the mechanical recording of laboratory research to concentrate on observing reading behavior, mainly his own. ${ }^{39}$ This consciously subjective methodology earned him much condemnation. Musicologist Gustav Becking, for example, who had worked with Sievers on the sound analysis of musical works during an adjunctship at Leipzig, complained in 1923 that although the method encouraged con-

37. W. E. Peters, “Stimmgebungsstudien. I: Der Einfluß der Sievers'schen Signale und Bewegungen auf die Sprachmelodie. Experimentalphonetisch untersucht," Psychologische Studien 10 (1917): 390-92.

38. Ibid., 388-89.

39. Sievers, Ziele und Wege, 3-4. 
centrated musical listening, in terms of research it constituted a "dead end." ${ }^{40}$ Whereas for Sievers the best sound analyst was an unprejudiced musical listener without prior training (ideally Sievers himself), for Becking music could only "come to life" through detailed knowledge of the work ${ }^{41}$ — but, Becking noted, such humanities knowledge was bound to inscribe itself into the unconscious motions accompanying listening. Because Sievers's method ignored these varying modes of reception, it lacked "humanities-based evidentiality," while its strong orientation on Sievers's own person also robbed it of objectivity and "scientific plausibility." 42

Nevertheless, Sievers's sound analysis initially remained popular as a resource for phonetic work on sound shifts, the study of poetic meter, and philological attempts to determine authorship. The latter was of interest particularly to classical philologists, medievalists, and theologians, but also to modern literary scholars as represented by the Germanist Julius Petersen. For his 1924 study of the famous conversations dictated by Goethe to his secretary, Johann Peter Eckermann, Petersen asked Sievers for an evaluation of the conversations' authenticity. Sievers believed he could identify the "Goethean word order" in individual remarks, but in other passages he heard the voice of Eckermann, from three distinct phases of writing and revision..$^{43}$ This sound analysis confirmed Petersen in his view that Eckermann had for the most part paraphrased the conversations and "all the speech had passed through his own medium." ${ }^{44}$ Sievers's method, Petersen concluded, offered clear insights over longer passages. ${ }^{45}$ Fifteen years later, however, Petersen dismissed sound analysis as obsolete and pointed out the miracle method's many sources of error, arising from "inaccurate sound reproduction and the erroneous reception of what is heard." ${ }^{\prime 6}$ Sievers's procedure was deeply subjective, suggestive, and irrational — far removed from a "reliable, manageable method." ${ }^{47}$

40. Gustav Becking, "Über ein dänisches Schulliederbuch, über Mitbewegungen und Gehaltsanalysen," Zeitschrift für Musikwissenschaft 6 (1923-24): 195. On collaboration between Becking and Sievers, see Arne Stollberg, “'Mimische Ausdruckshandlungen': Der Dirigentenkörper im anthropologischen Musikdiskurs des 19. und 20. Jahrhunderts," in DirigentenBilder: Musikalische Gestik—verkörperte Musik, ed. Arne Stollberg, Jana Weißenfeld, and Florian Henri Besthorn (Basel: Schwabe, 2015), 15-47.

41. Becking, "Über ein dänisches Schulliederbuch," 195.

42. Ibid., 194.

43. Julius Petersen, Die Entstehung der Eckermannschen Gespräche und ihre Glaubwürdigkeit, 2nd ed. (Frankfurt: Diesterweg, 1925), 101 and 103; see Stefan Rieger, "Medium/Philologie," in Eduard Sievers, Rhythmisch-melodische Studien, ed. Patrick Flack (Geneva: SDVIG, 2014), 55-65.

44. Petersen, Entstehung, 103.

45. Ibid., 100.

46. Julius Petersen, Die Wissenschaft von der Dichtung: System und Methodenlehre der Literaturwissenschaft (Berlin: Junker und Dünnhaupt, 1939), 106.

47. Ibid., 107. 


\section{RE-EXPERIENCING THEATER PERFORMANCES}

Between Petersen's first and second judgments lay the 1931 essay "Das theatralische Raumerlebnis" (The theatrical experience of space) by Berlin theater scholar Max Herrmann. Aesthetic experience in the theater, Herrmann postulated, relies crucially on the audience's co-creative activity (mitschöpferische Tätigkeit). This consists "in a secret re-experiencing [Nacherleben], in a shadowy recreation of the actor's work, in reception not so much through the sense of vision as through the sensations of the body, in a covert compulsion to execute the same movements, to produce the same timbre in the throat. Very few spectators are conscious of this process; however, it is often perfectly possible to become conscious of it." ${ }^{\text {" }}$

The essay's comments on the "secret re-experiencing" of performances pick up on attempts to re-experience the auctorial voice in the field of experimental psychology and phonetics outlined above. Although Herrmann, who had been trained as a Germanist, knew his colleague Petersen's work, he did not cite it. This may have been partly for personal reasons. From 1920, Petersen directed the department of German studies in Berlin, as well as heading the university's first department of theater studiesTheaterwissenschaft — with Herrmann from 1923. ${ }^{49}$ Theater studies departments were also founded in Cologne and Munich during the 1920s, investigating theater history and making intercultural comparisons. ${ }^{50}$ What distinguished Herrmann's Theaterwissenschaft from that of his colleagues was his quest for a psychological and sociological aesthetics of theater, based on a multidisciplinary program of studies that embraced psychology, sociology, economics, jurisprudence, and much more. ${ }^{51}$ Herrmann thus situated theater studies in the midst of the humanities, but also as something that went beyond their boundaries. However, Herrmann, as a Jew, had faced restrictions as director of the department from the start. In 1933, he was banned from practicing his profession - whereas Petersen had committed to Nazism early on and, after Herrmann's exclusion, continued to direct the department alone. It is not unlikely that in 1931

48. Max Herrmann, “Das theatralische Raumerlebnis," Zeitschrift für Ästhetik und allgemeine Kunstwissenschaft 25, supplement (1931): 159.

49. See Stefan Corssen, Max Herrmann und die Anfänge der Theaterwissenschaft (Tübingen: Niemeyer, 1998), 1-175; Martin Hollender, Der Berliner Germanist und Theaterwissenschaftler Max Herrmann (Berlin: Staatsbibliothek zu Berlin, 2013).

50. Carl Niessen, “Aufgaben der Theaterwissenschaft," Die Scene 17 (1927): 44-49; Artur Kutscher, Grundriss der Theaterwissenschaft (Düsseldorf: Pflugschar, 1932-1936).

51. Max Herrmann, "Über die Aufgabe eines theaterwissenschaftlichen Institutes" (1920), Wissenschaftliche Zeitschrift der Humboldt-Universität zu Berlin, gesellschafts- und sprachwissenschaftliche Reihe 23, nos. 3-4 (1974): 351-53. 
Herrmann was already endeavoring to distance his writings on theater aesthetics from Petersen's methodological approaches.

A further explanation for the absence of references to Petersen in "Das theatralische Raumerlebnis" may be that Herrmann's talk of the "secret re-experiencing," or Nacherleben, of events on the stage does not evoke the "stimulus-response schemata" developed by experimental psychophysiologists including Wundt or Pintner and applied in the humanities by scholars such as Sievers or Petersen. Herrmann describes Nacherleben as such a sensitive process that "an unfavorable emotional contagion of the total audience body" may reduce the effectiveness of the elements that foster it. ${ }^{52}$ A skillful director must therefore focus on first-rate acting and avoid the spectators being excessively distracted by the stage sets and scene changes. ${ }^{53}$ More generally, Herrmann argues, there is no such thing as a single theatrical experience of space, covering all spectators - only experiences in the plural, deriving from the multifariousness of theatrical art and the heterogeneity of the audience..$^{54}$ In this sense, Herrmann considered the Nacherleben of events on the stage to be an individually variable act-not unlike Stumpf's "laryngeal innervations" in music listening.

The closeness between Herrmann and Stumpf may stem from their having had the same mentor, Wilhelm Dilthey. Max Herrmann studied with Dilthey, describing him as an important teacher and maintaining contact with him later through the Society for German Literature. ${ }^{55}$ Dilthey's influence is apparent in Herrmann's early work, such as a 1900 study attempting to empathetically enter "the psyche of the young Goethe."56 The talk of the "secret re-experiencing" of events on the stage also evokes Dilthey, who had introduced the notion of Nacherleben as a central methodological category of historical hermeneutics in $1910 .^{57}$ Dilthey's concern was not the unconscious physical reaction to art (indeed, he fulminated against the stimulus-response schemata of experimental psychophysiology), but the intellectual re-experiencing of complex symbolic and expressive worlds. According to Dilthey, human beings are born into sym-

52. Herrmann, "Das theatralische Raumerlebnis," 160.

53. Ibid., 160-62.

54. Ibid., 163.

55. See Hollender, Max Herrmann, 21 and 144-53.

56. Max Herrmann, Jahrmarktsfest zu Plundersweilern: Entstehungs- und Bühnengeschichte (Berlin: Weidmann, 1900), v, and see also "Die Sprache als Material literaturpsychologischer Forschung," Zeitschrift für Pädagogische Psychologie 1, no. 1 (1899): 45-47. Herrmann's Jahrmarktsfest has been dubbed a literary study "with Diltheyian ambitions" (Stefan Hulfeld, Theatergeschichtsschreibung als kulturelle Praxis: Wie Wissen über Theater entsteht [Zurich: Chronos, 2007], 277).

57. Wilhelm Dilthey, "Transposition, Re-creating and Re-experiencing," in The Formation of the Historical World in the Human Sciences, trans. Michael Neville and ed. Rudolf A. Makkreel and Frithjof Rodi (1910; Princeton, NJ: Princeton University Press, 2002), 234-37. 
bolic worlds, which define their experience. As a result, humans can also create new symbolic worlds and can understand and re-experience historical ones. ${ }^{58}$ Dilthey illustrated this by describing a visit to the theater: "When the curtain goes up and Richard appears, sensitive spectators attending to his words, facial expressions, and movements can re-experience [nacherleben] something that lies outside any possibility in their real life." ${ }^{59}$ In Dilthey's theater, the audience's empathetic experience is neither with Shakespeare's Richard nor with the voice of the actor playing him, but with the spirit of fifteenth-century England.

Herrmann, in contrast, was seeking a different, not purely intellectual form of historiography. In his Forschungen zur Deutschen Theatergeschichte des Mittelalters und der Renaissance (Research on the theater history of the German Middle Ages and Renaissance) of 1914, Herrmann, like Dilthey, stresses the need to reconstruct historical performances and their symbolism in precise detail, but finds it most important of all to "breathe life into the paper investigations by transposing them into the practice of one's own voice, one's own body, one's own soul." ${ }^{\prime 60}$ As time went on, Herrmann became even less faithful to his teacher Dilthey, partly in his aspiration to open up theater studies to a wide range of research fields within and beyond the humanities, and partly in his determination to distance himself from every existing method in phonetics, literary studies, and musicology and outline a completely separate aesthetics of effect for the theatrical arts, independent of other artistic genres. This may explain why "Das theatralische Raumerlebnis" also contains no mention of Herrmann's earlier ventures in literary hermeneutics. Instead, the essay reflects Herrmann's interest in experimental physiology - the very research field that Dilthey had attacked for its orientation on the natural sciences, but that he had also supported (though unintentionally) in the person of Carl Stumpf. Herrmann suggested, for example, studying the impact of theater architecture on the performance of actors, noting that experimental psychology had hitherto paid almost no attention to the impact of space on the human habitus. He conversed about possible projects with psychologist Kurt Lewin, then a colleague of Stumpf's. ${ }^{61}$ If his teacher Dilthey had invoked symbolic worlds as the guardians of historical continuity, then, Herrmann — much like Stumpf — put his faith in the bodily re-experience

58. Wilhelm Dilthey, "Fundamental Relationship: The Structure of Historical Formations," in The Formation of the Historical World in the Human Sciences, vol. 3 of Selected Works, trans. Michael Neville and ed. Rudolf A. Makkreel and Frithjof Rodi (1910; Princeton, NJ: Princeton University Press, 2002), 275.

59. Dilthey, “Transposition," 236.

60. Max Herrmann, Forschungen zur deutschen Theatergeschichte des Mittelalters und der Renaissance (Berlin: Weidmann, 1914), 7.

61. See Herrmann, "Das theatralische Raumerlebnis," 156. 
of theatrical history and theater performance, formed by hermeneutics but conceived of psychophysically. ${ }^{62}$

\section{THE LARYNXES OF THE ARTS}

Today, "empirical aesthetics," a field of interdisciplinary research on aesthetic perception and evaluation that draws on both science and the humanities, has been flourishing for some years. ${ }^{63}$ Yet empirical aesthetics has a long prehistory; specifically, the life sciences and the arts around 1900 crossed disciplinary boundaries to answer the questions of aesthetics. The emergence of comparably interdisciplinary research initiatives around a century later is often explained by structural similarities in the two eras' natural and neurological sciences, technologically innovative and open to humanitiesrelated themes. This is doubtless true for the multidisciplinary interest in the movements of the human larynx I have described, so hard to perceive yet becoming more measurable around 1900. But that interest was not motivated solely by an increasingly technologized and thematically open psychophysiology.

For one thing, the writings on the involuntary laryngeal movements of music listeners, readers, and theater audiences that I have discussed shared an interest in experimental aesthetics but diverged substantially in their approach to the natural sciences. As we have seen, the experimental psychologists Wilhelm Wundt and Rudolf Pintner and the phonetician Eduard Sievers used precision technologies to measure and define modes, types, or even laws of aesthetic perception in a seemingly objective way. Sievers's reader research, in turn, gave even leading Germanists such as Julius Petersen reason to believe that the voices of dead writers moved in the larynx of the skilled and sensitive experimental subject. To oppose this assumption, the music theorist Gustav Becking, another colleague of Sievers, later specified that the inner movements accompanying musical listening depended not only on the composition itself, but also on the listener's knowledge - humanities knowledge - about that composition. For theater scholar Max Herrmann, too, the "secret re-experiencing" of historical and contemporary theater was a physical process, but also an individual one dependent on humanities

62. Besides Stumpf, Herrmann certainly also read the popular science publications of Fritz Mauthner, who likewise addressed the psychophysiology of human attention and the "motions in the larynx" that accompanied it. "There are people," Mauthner wrote, "who, when they listen to a crisply accented reading, feel the same articulatory movements that we have observed for silent thought. The vocal artists among professional actors claim to have felt hoarse after listening for a long period" (Sprache und Psychologie [Stuttgart: Cotta, 1901], 467). See Max Herrmann, "Über Theaterkunst," lecture notes by Johannes Günther, 1918, reproduced in Corssen, Max Herrmann, 291.

63. See the presentation of the Max Planck Institute for Empirical Aesthetics, https://www.aesthetics .mpg.de/en/the-institute.html. 
knowledge. A glance at earlier writings by Herrmann reveals that, in the founding phase of theater studies, he exploited the still open boundaries of the program of humanities and drew inspiration from thinking on theater in other fields, including the aesthetics of empathy and experimental aesthetics, as represented by philosophers such as Carl Stumpf and Karl Groos. By following Stumpf and Groos and by sketching a physiology of historiographical reading, then of spectatorship, Herrmann also departed from his mentor Dilthey. For Dilthey, the hermeneutic method of empathy was based on intellectual competences (as developed in the humanities), whereas Herrmann envisaged a theater studies that addressed and applied physical experiences, with an aesthetics that bridged the humanities and the natural sciences.

In Herrmann's time, the relationship between individual disciplines in the humanities was acquiring its own momentum - defined, on the one hand, by interdisciplinarity and a network of scholars all seeking to utilize the insights of physiological aesthetics for their own domain and, on the other, by methodological innovations that were driven by legitimatory pressure and subject rivalry inside the humanities. From the 1910s to the 1930s, literary studies, musicology, and theater studies seem to have competed as to which media context (reading books, visiting a concert, experiencing theatrical space) could most successfully take its recipients "by the throat" and offer insights into inner speech. In his own subject field, Herrmann found few allies during the short period of his professional activity, while present-day studies on the aesthetics of effect in theatrical and performance art frequently return to his audience research to argue again that the immediate, physical impact on the audience is what privileges theater over literary drama, film, and the visual arts. ${ }^{64}$

Comparing the endeavors around 1900 with present-day aspirations to a new empirical aesthetics, one may thus doubt whether today's research trend is really due primarily to the impact of innovative technologies and methods from neuroscience. The impulse to answer aesthetic questions using empirical and experimental methods has, it seems, always also come from the humanities themselves.

\section{WORKS CITED}

Becking, Gustav. 1923-24. "Über ein dänisches Schulliederbuch, über Mitbewegungen und Gehaltsanalysen." Zeitschrift für Musikwissenschaft 6:191-218.

Brain, Robert M. 2008. "The Pulse of Modernism: Experimental Physiology and Aesthetic AvantGardes circa 1900." Studies in History and Philosophy of Science Part A 39 (3): 393-417.

- 2015. The Pulse of Modernism: Physiological Aesthetics in Fin-de-Siècle Europe. Seattle: University of Washington Press.

Corssen, Stefan. 1998. Max Herrmann und die Anfänge der Theaterwissenschaft. Tübingen: Niemeyer.

64. Erika Fischer-Lichte, Performativität: Eine Einführung (Bielefeld: transcript-Verlag, 2012), 20. 
Courten, H. C. 1902. "Involuntary Movements of the Tongue." Yale Psychological Studies 10:93-95. Curtis, H. S. 1900. “Automatic Movements of the Larynx.” American Journal of Psychology 11 (2): 237-39. Dilthey, Wilhelm. (1910) 2002a. "Fundamental Relationship: The Structure of Historical Formations." In The Formation of the Historical World in the Human Sciences, vol. 3 of Selected Works, translated by Michael Neville and edited by Rudolf A. Makkreel and Frithjof Rodi, 273-81. Princeton, NJ: Princeton University Press.

. (1910) 2002b. "Transposition, Re-creating and Re-experiencing." In The Formation of the Historical World in the Human Sciences, vol. 3 of Selected Works, translated by Michael Neville and edited by Rudolf A. Makkreel and Frithjof Rodi, 234-37. Princeton, NJ: Princeton University Press. - 1989. Introduction to the Human Sciences. Vol. 1 of Selected Works. Translated by Michael Neville, edited by Rudolf A. Makkreel and Frithjof Rodi. Princeton, NJ: Princeton University Press. Fischer-Lichte, Erika. 2012. Performativität: Eine Einführung. Bielefeld: transcript-Verlag.

Groos, Karl. 1892. Einleitung in die Aesthetik. Giessen: Ricker.

1902. Der aesthetische Genuss. Giessen: Ricker.

. 1909. "Das ästhetische Miterleben und die Empfindungen aus dem Körperinnern.” Zeitschrift für Ästhetik und allgemeine Kunstwissenschaft 4:161-82.

Guthmüller, Marie, and Wolfgang Klein. 2006. "Einleitung: Ästhetik von unten-Empirie und ästhetisches Wissen.” In Ästhetik von unten, edited by Marie Guthmüller and Wolfgang Klein, 1-20. Tübingen: A. Francke.

Hagner, Michael. 2006. Der Geist bei der Arbeit: Historische Untersuchungen zur Hirnforschung. Göttingen: Wallstein.

Herrmann, Max. 1899. "Die Sprache als Material literaturpsychologischer Forschung." Zeitschrift für Pädagogische Psychologie 1 (1): 45-47.

—. 1900. Jahrmarktsfest zu Plundersweilern: Entstehungs- und Bühnengeschichte. Berlin: Weidmann.

- 1914. Forschungen zur deutschen Theatergeschichte des Mittelalters und der Renaissance. Berlin: Weidmann.

- (1920) 1974. "Über die Aufgabe eines theaterwissenschaftlichen Institutes." Wissenschaftliche Zeitschrift der Humboldt-Universität zu Berlin, gesellschafts- und sprachwissenschaftliche Reihe 23 (3-4): 351-53.

—. 1931. "Das theatralische Raumerlebnis." Zeitschrift für Ästhetik und allgemeine Kunstwissenschaft 25, supplement: 152-63.

Hollender, Martin. 2013. Der Berliner Germanist und Theaterwissenschaftler Max Herrmann (18651942). Berlin: Staatsbibliothek zu Berlin.

Hulfeld, Stefan. 2007. Theatergeschichtsschreibung als kulturelle Praxis: Wie Wissen über Theater entsteht. Zurich: Chronos.

Kutscher, Artur. 1932-1936. Grundriss der Theaterwissenschaft. 2 vols. Düsseldorf: Pflugschar.

Lanzoni, Susan. 2012. "Introduction: Emotion and the Sciences." Science in Context 25 (3): 287-300.

Mauthner, Fritz. 1901. Sprache und Psychologie. Stuttgart: Cotta.

Meyer-Kalkus, Reinhart. 2001. Stimme und Sprechkünste im 20. Jahrhundert. Berlin: Akademie-Verlag. Müller-Tamm, Jutta, Henning Schmidgen, and Tobias Wilke. 2014. "Empirische Ästhetik um 1900: Zur Einführung." In Gefühl und Genauigkeit, edited by Jutta Müller-Tamm, Henning Schmidgen, and Tobias Wilke, 7-24. Munich: Fink.

Niessen, Carl. 1927. “Aufgaben der Theaterwissenschaft.” Die Scene: Blätter für Bühnenkunst 17:44-49.

Peters, W. E. 1917. "Stimmgebungsstudien. I: Der Einfluß der Sievers'schen Signale und Bewegungen auf die Sprachmelodie. Experimentalphonetisch untersucht.” Psychologische Studien 10:387-570.

Petersen, Julius. 1925. Die Entstehung der Eckermannschen Gespräche und ihre Glaubwürdigkeit. 2nd ed. Frankfurt: Diesterweg. 
1939. Die Wissenschaft von der Dichtung: System und Methodenlehre der Literaturwissenschaft. Berlin: Junker und Dünnhaupt.

Pintner, Rudolf. 1913a. "Inner Speech during Silent Reading." Psychological Review 20 (2): 129-53.

- 1913b. Untersuchungen über die Aufmerksamkeitsformen beim Lesen und Reagieren. Leipzig: Alfred Hahn.

Rieger, Stefan. (1912) 2014. “Medium/Philologie.” In Eduard Sievers, Rhythmisch-melodische Studien, edited by Patrick Flack, 7-66. Geneva: SDVIG.

Rothacker, Erich, ed. 1923. Briefwechsel zwischen Wilhelm Dilthey und dem Grafen Paul Yorckv. Wartenburg, 1877-1897. Halle: Max Niemeyer.

Rousselot, Jean-Pierre. 1897-1901. Principes de phonétique expérimentale. Vol. 1. Paris: H. Didier.

Rutz, Ottmar. 1911. Musik, Wort und Körper als Gemütsausdruck. Leipzig: Breitkopf \& Härtel.

Schnitzler, Johann. 1895. Klinischer Atlas der Laryngologie nebst Anleitung zur Diagnose und Therapie der Krankheiten des Kehlkopfes und der Luftröhre. Vienna: Braumüller.

Schrötter, Leopold. 1887. Vorlesungen über die Krankheiten des Kehlkopfes, der Luftröhre, der Nase und des Rachens. Vienna: Wilhelm Braumüller.

Siegert, Bernhard. 1999. "Das Leben zählt nicht: Natur- und Geisteswissenschaften bei Dilthey aus mediengeschichtlicher Sicht." In Medien: Dreizehn Vorträge zur Medienkultur, edited by Claus Pias, 161-82. Weimar: VDG.

Sievers, Eduard. (1894) 1912. "Zu Rhythmik und Melodik des neuhochdeutschen Sprechverses." In Rhythmisch-melodische Studien, 36-55. Heidelberg: Winter.

—. (1901) 1912. "Über Sprachmelodisches in der deutschen Dichtung." In Rhythmisch-melodische Studien, 56-77. Heidelberg: Winter.

_. (1903) 1912. "Über ein neues Hilfsmittel philologischer Kritik." In Rhythmisch-melodische Studien, 78-111. Heidelberg: Winter.

- 1914. "Neues zu den Rutzschen Reaktionen." Archiv für experimentelle und klinische Phonetik $1: 225-52$.

-1918. Metrische Studien IV: Die Altschwedischen Upplandslagh nebst Proben formverwandter Germanischer Sagdichtung. Berlin: Springer.

- 1924. Ziele und Wege der Schallanalyse: Zwei Vorträge. Heidelberg: Winter.

Stollberg, Arne. 2015. “'Mimische Ausdruckshandlungen': Der Dirigentenkörper im anthropologischen Musikdiskurs des 19. und 20. Jahrhunderts.” In DirigentenBilder: Musikalische Gestik—verkörperte Musik, edited by Arne Stollberg, Jana Weißenfeld, and Florian Henri Besthorn, 15-47. Basel: Schwabe.

Stricker, Salomon. 1882. Studien über die Bewegungsvorstellungen. Vienna: Braumüller.

Stumpf, Carl. 1883. Tonpsychologie. Vol. 1. Leipzig: Hirzel.

Tkaczyk, Viktoria. Forthcoming. "Max Herrmann und die Austreibung des Geistes aus der Theaterwissenschaft." In Perspektiven auf Max Herrmann: 100 Jahre Forschungen zur deutschen Theatergeschichte, edited by Stephan Dörschel and Matthias Warstat. Berlin: Gesellschaft für Theatergeschichte.

Ungeheuer, Gerold. 1977. Sprache und Signal. Hamburg: Buske.

Wundt, Wilhelm. 1900. Die Sprache: Erster Teil. Vol. 1 of Völkerpsychologie. Leipzig: Engelmann. 